\title{
Pelatihan Pembuatan Nutrisi Sehat dan Menarik sebagai Bekal Anak Sekolah
}

\author{
Nora Wulandari ${ }^{1}$, Vivi Anggia ${ }^{2}$, Tuti Wiyati ${ }^{2}$ \\ 1,2 Universitas Muhammadiyah Prof. Dr. Hamka
}

\begin{abstract}
Article History ABSTRACT
Received 08.08.2019

Received in revised form 10.09.2019

Accepted 18.10.2019

Available online 28.10.2019

TRAINING ON MAKING HEALTHY AND ATTRACTIVE NUTRITION AS FOOD FOR CHILDREN IN SCHOOL. This community service program was motivated by hazardous food found in schools in the DKI Jakarta area. The purpose of this community service activity was as an effort to promote health in realizing the community, especially the healthy of young people by making it a habit to consume snacks or healthy foods that are unique and attractive in the form of bento. The community service was carried out by means of socialization and counseling followed by a direct demonstration of making bento to the target audience, namely the students' parents and the Al-Hikma Kindergarten school committee Perumnas Klender, East Jakarta. This activity showed a positive response from the participants which was shown from the enthusiastic participants' devotion in participating in the activities as well as being potential entrepreneurs in schools in the East Jakarta area. The outputs obtained from this activity were: a) creation of community understanding, especially housewives on the importance of healthy nutrition for children, b) increasing community creativity in making attractive healthy food as provisions for school children, c) entrepreneurial opportunities for housewives which can increase community income.
\end{abstract}

KEYWORDS: Bento, Health Nutrition, Young Student. Attribution 4.0 International License, which permits unrestricted use, distribution, and reproduction in any medium, provided the original work is properly cited. ○) 2019 Nora Wulandari, Vivi Anggia, Tuti Wiyati.

\section{PENDAHULUAN}

Perkembangan seorang anak sangat dipengaruhi oleh zat gizi yang dikonsumsinya sehari-hari. Pola makan merupakan perilaku paling penting yang dapat mempengaruhi keadaan gizi. Hal ini disebabkan karena kuantitas dan kualitas makanan dan minuman yang dikonsumsi akan mempengaruhi tingkat kesehatan individu dan masyarakat. Keadaan gizi seorang anak akan mempengaruhi tidak saja perkembangan fisik tetapi juga

\footnotetext{
${ }^{1}$ Corresponding author: Fakultas Farmasi dan Sains, Universitas Muhammadiyah Prof. Dr. HAMKA (UHAMKA), Jl. DelimaII/IV Islamic Center, Malaksari, Duren Sawit, Jakarta Timur, 13460; Email: wulandari.nora@uhamka.ac.id
} 
kecerdasan, ketangkasan berpikir hingga produktivitas kerjanya terutama di usia sekolah. Anak sekolah tidak terlepas dari pangan jajanan. Makanan selain mengandung nilai gizi juga merupakan media untuk dapat berkembang biaknya mikroba atau kuman. Salah satu kelompok masyarakat yang sering mengalami masalah akibat keracunan makanan adalah anak sekolah. Jajanan anak sekolah berisiko terhadap cemaran biologis atau kimiawi yang banyak mengganggu kesehatan, baik jangka pendek maupun jangka Panjang (Nurbiyati \& Wibowo, 2014).

Dalam rangka mendukung ketahanan pangan dan gizi yang baik, dimulai dari pengawalan pangan jajanan anak sekolah termasuk pengawasan kantin, KIE yang holistik hingga terjadi perubahan mental dalam mengkonsumsi makanan yang sehat. Dalam pembangunan kesehatan, Kementerian Kesehatan Republik Indonesia berusaha memperkuat kesehatan dasar/pelayanan kesehatan primer, sehingga dapat menjaga kesehatan di dalam keluarga (BPOM RI, 2017). Oleh karena itu diharapkan anak-anak usia sekolah dapat mengkonsumsi makanan yang sehat. Namun, dari hasil pengawasan Pangan Jajanan Anak Sekolah (PJAS) masih ditemukan pangan berbahaya sekitar 4,3\% pada tahun 2016 (BPOM RI, 2019).

Hasil penelitian lain mengenai gambaran tentang pemilihan jajanan pada anak usia sekolah didapatkan hasil pemilihan terkait makanan sebanyak 54,3\% memilih makanan jajanan yang tidak sehat, terkait personal sebanyak $64,5 \%$ memilih makanan jajanan yang tidak sehat, terkait sosial-ekonomi sebanyak 55,4\% memilih makanan jajanan yang tidak sehat, dan pemilihan terkait ketersediaan makanan jajanan di sekolah mendapatkan hasil bahwa anak-anak memilih makanan jajanan yang tidak sehat (Iklima, 2017). Hasil uji laboratorium terhadap 19 geplak berwarna merah menunjukkan 1 sampel geplak positif Rhodamin B (5,3\%), dan dari 10 sampel geplak berwarna kuning tidak ada yang mengandung Methanyl Yellow (Rahayu \& Mahmuda, 2016).

Dalam penelitian yang dilakukan di 68 SD di kabupaten Bantul didapatkan jenis makanan jajanan yang diduga mengandung bahan kimia berbahaya yang paling banyak dijajakan di SD adalah jenis bakso (bakso, bakso tusuk, bakso goreng) yaitu sejumlah $22,4 \%$ dari seluruh sampel jajanan. Di antara 98 sampel yang diuji kandungan boraks dan formalinnya, 15 sampel (15,3\%) positif mengandung boraks dan 25 sampel $(25,5 \%)$ positif mengandung formalin. Di antara 15 sampel yang diuji kandungan rhodamin-B-nya, 7 sampel (46,7\%) positif mengandung rhodamin-B. Terdapat 34 SD (50\%) yang tidak terdapat jajanan yang tercemar bahan kimia berbahaya (Paratmanitya \& Aprilia, 2016).

Dari berbagai kajian mengenai formaldehid yang terkandung dalam formalin, disimpulkan bahwa bahan tersebut bersifat karsinogenik pada manusia, di mana efek karsinogenik ini dapat bersifat akut atau kronis dan dalam jangka waktu Panjang dapat menyebabkan kerusakan organ dalam tubuh seperti jantung, hati, otak, dan juga reproduksi (WHO, 2006). Sedangkan penggunaan pewarna makanan seperti RhodaminB dapat mebahayakan kesehatan. Penggunaan dalam jangka Panjang dapat menyebabkan gangguan fungsi hati, pembesaran hati dan ginjal, gangguan fisiologis tubuh, bahkan dapat menyebabkan timbulnya kanker hati (BPOM RI, 2011).

TK/KB Al-Hikmah terletak di wilayah Perumans Klender berjarak sekitar 500-meter dari Fakultas Farmasi dan Sains Universitas Muhammadiyah Prof. DR. HAMKA, Jakarta Timur. Di sekitar sekolah ini terdapat berbagai makanan yang di jual oleh pedagang yang ramai dikerumuni oleh siswa-siswa sekolah di daerah sekitar. Hal ini dirasa perlu bagi 
para orang tua murid di sekolah TK/KB Al-Hikmah untuk dapat menyediakan sendiri bekal bagi anak-anak mereka. Namun, para orang tua murid masih mengeluh karena jajanan yang tersedia lebih menarik. Oleh karena itu, pengabdian kali ini dilakukan untuk memberikan penyuluhan mengenai nutrisi yang sehat dan pelatihan pembuatan bento dengan bentuk yang menarik sebagai bekal untuk anak.

\section{METODE PELAKSANAAN}

Program pengabdian masyarakat ini dilaksanakan pada bulan Maret- April 2019 dengan lokasi kegiatan di TK/KB AL-Hikma Perumnas Klender, Malakasari, Duren Sawit, Jakarta Timur. Peserta kegiatan ini adalah wali murid (orang tua) dan komite sekolah TK/KB Al-Hikma.

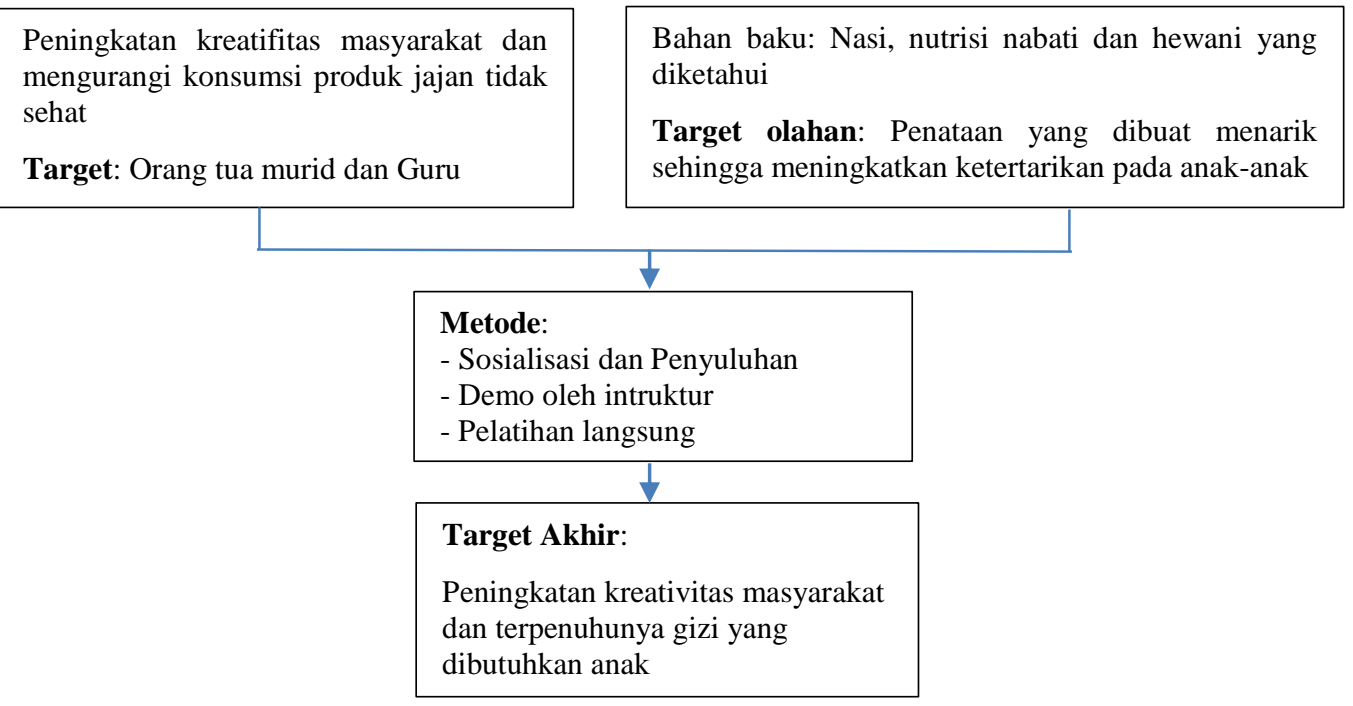

Gambar 1. Skema Kegiatan

Bahan yang digunakan untuk pembuatan Bento meliputi: sumber karbohidrat berupa nasi, sumber nabati berupa sayur-sayuran seperti wortel, brokoli, daun selada, jagung, snack rumput laut, serta sumber hewani berupa telur puyuh, nugget, sosis, dan abon. Sedangkan alat yang digunakan untuk membuat produk Bento: box pengemas makanan, sendok, cetakan makanan berbentuk tokoh kartun, sarung tangan plastik, pisau, gunting, pinset, talenan dan lain-lain.

Program pengabdian masyarakat ini dilakukan dalam tiga tahap, yaitu persiapan, pelaksanaan, dan evaluasi. Pada tahap persiapan, dilakukan penyiapan bahan baku serta peralatan yang dibutuhkan dan praktik uji coba pembuatan bento. Selanjutnya pada tahap pelaksaanan, yang menjadi target utama program ini adalah para orang tua murid dan komite sekolah terutama kelompok ibu rumah tangga. Pemberian materi mengenai mengenai komposisi gizi yang penting untuk dan anak jajanan sehat untuk anak. Peserta disosialisasikan juga mengenai beberapa cara untuk membuat bento yang menarik melalui pemutaran video. Setelah pemberian materi, dilakukan demo pembuatan bento dan praktik secara langsung oleh peserta pengabdian proses pembuatan produk bento tersebut (Gambar 2). Tahap evaluasi dilakukan dengan mengumpulkan kesan dan pesan dari para peserta setelah kegiatan berakhir. 


\section{HASIL DAN PEMBAHASAN}

\section{Penyuluhan dan Diskusi}

Penyuluhan dilakukan di Ruang kelas TK/KB Al-Hikma Perumnas Klender Jakarta Timur yang melibatkan orang tua murid dan para guru serta komite sekolah TK/KB AlHikmah Perumnas Klender Jakarta Timur (Gambar 2). Adapun materi yang disampaikan adalah mengenai komposisi gizi yang penting untuk dan anak jajanan sehat untuk anak. Para orang tua murid dan guru diberikan informasi dari laporan BPOM yang menunjukkan bahwa sebagian besar dari sampel jajanan sekolah di wilayah DKI Jakarta tidak memenuhi syarat untuk dikonsumsi. Para orang tua murid juga diberikan edukasi beberpa bahan yang biasa ditemukan dalam jajanan tidak sehat tersebut berupa Borax pada makanan seperti otak-otak atau bakso, formalin pada tahu goreng dan mie kuning, dan rhodamine B pada minuman berwarna. Kemudian para orang tua murid dan guru diberikan pemahaman mengenai sumber dan pentingnya gizi yang seimbang yang mengandung karbohidrat, protein, lemak, air, vitamin, mineral dan serat yang harus penting tersedia pada makanan anak terutama usia sekolah.

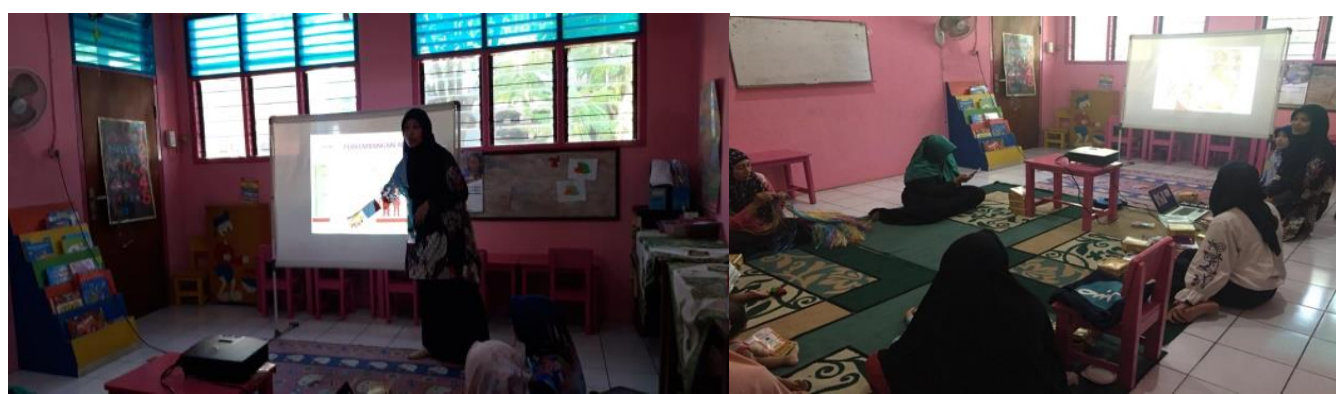

\section{Gambar 2. Proses Penyuluhan}

Hasil yang diperoleh dalam kegiatan sosialisasi dan penyuluhan ini adalah bertambahnya pemahaman dan keterampilan para orang tua murid dan guru dalam mengkreasikan makan bergizi yang menarik sehingga anak lebih tertarik untuk mengkonsumsinya. Sebagaimana hasil hail penelitian yang dilakukan menyebutkan bahwa dukungan dari orang tua supaya dapat merubah perilaku anak mengkonsumsi janajan di sekolah, misalnya dengan membiasakan anak sarapan pagi, membawa bekal ke sekolah (Angraini et al, 2019). Dari hasil penelitian didapatkan kesimpulan bahwa kandungan gizi dan keamanan jajanan anak sekolah perlu diingkatkan. Detiminan utama pemilihan jajanan didominasi aspek hrga, hadiah dan cita rasa (Kristianto, Riyadi, \& Mustafa, 2013).

\section{Demostrasi dan Pelatihan}

Pada pelatihan pembuatan produk dihasilkan produk kreativitas berupa bento yang berasal dari sumber karbohidrat berupa nasi, sumber nabati berupa sayur-sayuran seperti wortel, brokoli, daun selada, jagung, snack rumput laut, serta sumber hewani berupa telur puyuh, nugget, sosis, dan abon. Semua bahan-bahan tersebut ditata sedemikian rupa sehingga menyerupai took-toko kartun yang disukai oleh anak-anak. Pada Kegiatan pelatihan ini dihasilkan produk bento berbentuk toko kartun hello kitty dan doraemon (Gambar 2). 


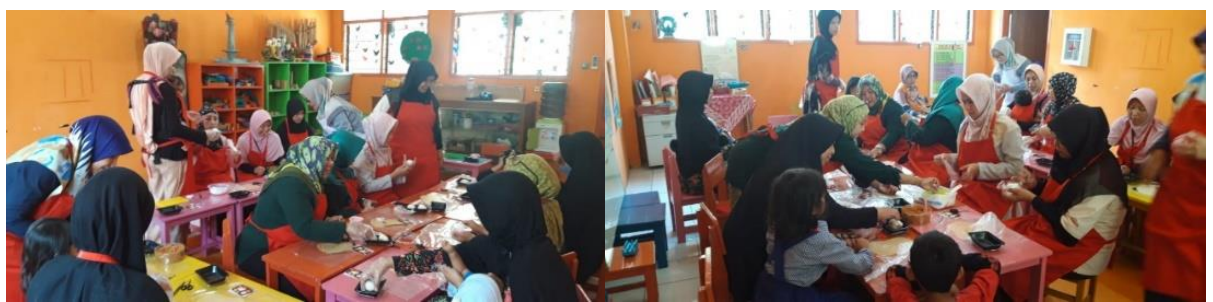

a) Proses Pembuatan Bento

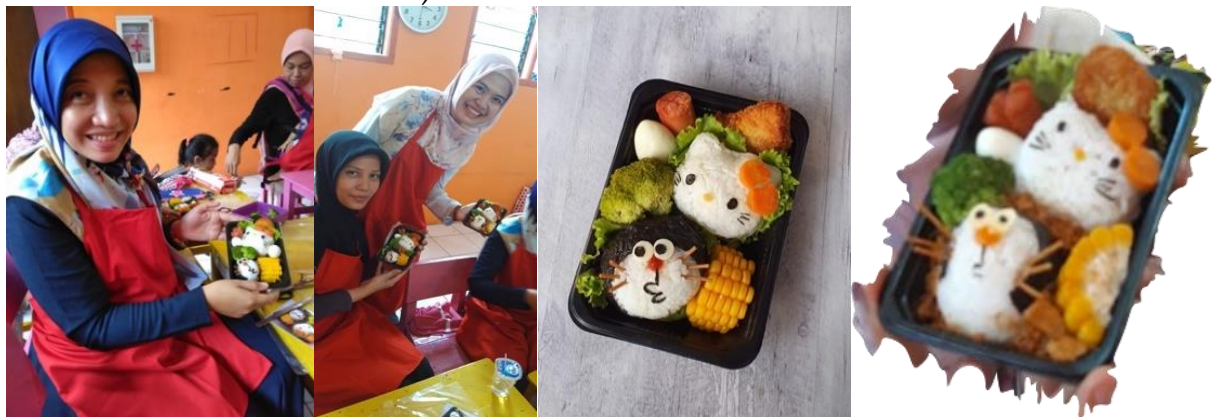

b) Bentuk Produk Bento yang Dihasilkan

Gambar 2. Proses Kegiatan Pembuatan Bento dan Produk Bento yang Dihasilkan

Tantangan utama yang dihadapi dalam pembuatan dan pengelolaan produk ini adalah kreativitas para orang tua khususnya para ibu untuk mengembangkan bentukbentuk bento yang sesuai dengan preferensi anak mereka sehingga dapat bersaing dengan jajanan-jajanan di sekolah mereka. Kelemahan mendasar dalam program-program pengembangan kreativitas masyarakat berbasis kreativitas seperti ini terletak pada masih rendahnya kemauan para ibu rumah tangga untuk menyiapkan produk produk yang dikemas menarik sebagai bekal untuk anak-anaknya. Selain itu waktu yang diperlukan untuk menyiapkan bekal-bekal seperti ini menurunkan antusias bagi para ibu rumah tangga. Namun dengan adanya edukasi akan bahayanya jajanan sembarangan yang tidak diketahui higienitas dan kesehatannya ini, diharapkan dapat meningkatkan kemauan para ibu untuk dapat menyiapkan sendiri bekal untuk anak-anaknya. Lebih lanjut, produk ini berpotensi untuk dikembangkan bagi para ibu rumah tangga sebagai lahan bisnis misalnya dengan membuka jasa catering bekal makanan sehat dilingkungan sekolah-sekolah di sekitar wilayah tempat tinggal mereka.

\section{SIMPULAN}

Kegiatan pengabdian seperti ini sangat bermanfaat bagi masyarakat khususnya bagi para orang tua murid sekolah yang biasa menyiapkan makanan bekal untuk anak-anak mereka. Antusias dan partisipasi aktif dari para peserta pengabdian sangat enunjang keberhasilan dari kegiatan ini. Kegiatan ini telah mampu memberikan keterampilah kepada peserta pengabdian tentang bagaimana cara menyiapkan bekal yang kreatif dan menarik namun juga bergizi bagi anak-anak mereka sehingga mengurangi dan mencegah anak-anak untuk mengkonsumsi makanan dari jajanan yang tidak diketahui kebersihan dan kesehatannya.

Berdasarkan kesan dan pesan yang disampaikan oleh peserta, mereka merasa kegiatan ini sangat memberikan manfaat bagi peserta dan diharapkan dapat dilakukan secara kontinu dengan bentuk-bentuk bento yang lain. 


\section{UCAPAN TERIMA KASIH}

Penulis mengucapkan terima ksih kepada Lembaga Pengabdian dan Pemberdayaan Masyarakat (LPPM) Universitas Muhammadiyah Prof. DR. HAMKA (UHAMKA) yang telag mendanai program ini dengan nomor kontrak 882/H.04.02/2019 tanggal 22 Mei 2019. Penulis juga mengucapkan terima kasih kepada Fakultas Farmasi dan Sains UHAMKA yang telah mendukung berjalannya program ini. Ucapan terima kasih juga penulis sampaikan kepada wali murid dan komite TK/KB Al-Hikma Perumnas Klender, Jakarta Timur.

\section{REFERENSI}

Angraini, W., Betrianita, B., Pratiwi, B. A., Yanuarti, R., \& Fermana, P. (2019). Pengaruh pendidikan kesehatan terhadap pengetahuan, sikap, dan frekuensi konsumsi makanan jajanan di kota Bengkulu. Jurnal Kesmas Asclepius, 1(1), 1-13.

BPOM RI. (2011). Bahaya rhodamin B sebagai pewarna pada makanan. Retrieved August 6, 2019 from http://ik.pom.go.id/v2016/artikel/Bahaya-Rhodamin-B-sebagai-Pewarnapada-Makanan.pdf

BPOM RI. (2017). Laporan tahunan Badan POM RI tahun 2017. Jakarta: Badan Pengawas Obat dan Makanan Republık Indonesıa

BPOM RI. (2019). Temuan pangan jajanan anak sekolah berbahaya di Jakarta terus menurun. $\begin{array}{llll}\text { Retrieved July 6, 2019, from } & \text { 6, }\end{array}$ https://www.pom.go.id/new/view/more/berita/12963/Temuan-Pangan-JajananAnak-Sekolah-Berbahaya-di-Jakarta-Terus-Menurun.html

Iklima, N. (2017). Gambaran pemilihan makanan jajanan pada anak usia sekolah dasar. Jurnal Keperawatan BSI, 5(1), 8-17.

Kristianto, Y., Riyadi, B. D., \& Mustafa, A. (2013). Faktor determinan pemilihan makanan jajanan pada siswa sekolah dasar. Kesmas: National Public Health Journal, 7(11), 489494.

Nurbiyati, T., \& Wibowo, A. H. (2014). Pentingnya memilih jajanan sehat demi kesehatan anak. Junal Inovasi dan Kewirausahaan, 3(3), 192-196.

Paratmanitya, Y., \& Aprilia, V. (2016). Kandungan bahan tambahan pangan berbahaya pada makanan jajanan anak sekolah dasar di Kabupaten Bantul. Jurnal Gizi dan Dietetik Indonesia (Indonesian Journal of Nutrition and Dietetics), 4(1), 49-55.

Rahayu, M., \& Mahmuda, Y. I. (2016). Identifikasi zat pewarna rhodamin B dan methanyl yellow pada kerupuk yang dijual di pasar Beringharjo Yogyakarta tahun 2016. Jurnal Teknologi Laboratorium, 5(2), 55-58.

WHO. (2006). IARC monographs on the evaluation of carcinogenic risks to humans. zarc monographs on the evaluation of carcinogenic risks to humans, Volume 88. Retrieved July 6, 2019 from https://monographs.iarc.fr/wp-content/uploads/2018/06/mono88.pdf 